\title{
Gyógyítás és interkulturalitás
}

\section{Interculturality and healthcare provision}

Szerzők: $\quad$ Marek Erika ${ }^{a} \bowtie$, Schmél Dóra ${ }^{a}$, Katz Zoltán ${ }^{a}$, Faubl Nóra ${ }^{b}$, Németh Tímeac, Berényi Károly ${ }^{\text {, Szilárd István }}{ }^{\mathrm{a}}$

a: Pécsi Tudományegyetem, Általános Orvostudományi Kar, Müveleti Medicina Tanszék, b: Pécsi Tudományegyetem, Általános Orvostudományi Kar, Magatartástudományi Intézet, c: Pécsi Tudományegyetem, Általános Orvostudományi Kar, Egészségügyi Nyelvi és Kommunikációs Intézet, d: Pécsi Tudományegyetem, Általános Orvostudományi Kar, Orvosi Népegészségtani Intézet

Beküldve: 2019. 06. 20.

doi: $\quad$ 10.24365/ef.v60i4.493

\begin{abstract}
Összefoglaló:
Bevezetés: A 2013 óta drámai mértékben megnőtt menekülthullám váratlan kihívások elé állította az Európai Unió egészségügyi ellátórendszereit. A 2015-ös tömeges bevándorlás okozta krízis hívta életre az Egészségügyi Világszervezet (World Health Organization, WHO) által szervezett „Menekültek és migránsok egészsége” csúcstalálkozót (High-level meeting on Refugee and Migrant Health), melynek záródokumentuma rámutat az ún. „migránsérzékeny egészségügyi ellátórendszer" kialakításának és az egészségügyi dolgozók képzésének fontosságára, tekintettel a bevándorló népesség nyelvi, vallási és kulturális sokszínűségére. Kutatási céljaink között szerepel ezen ajánlások mentén vizsgálni a Pécsi Tudományegyetem Általános Orvosi Kar (PTE-ÁOK) hallgatóinak felkészültségét, jelenlegi interkulturális kompetenciaszintjét és azonosítani az esetleges hiányosságokat és fejlesztendő területeket.
\end{abstract}

Módszerek: Kérdőíves felmérésünket a Pécsi Tudományegyetemen (PTE) a 2016-2017-es tanév során a magyar nyelvű képzésben részt vevő 1., valamint 4. és 5 . évfolyamot végző orvostanhallgatók körében végeztük el. Kutatásunk során összesen 391 kérdőívet értékeltünk, a válaszadói ráta 83,9\%-os volt. Felmérésünkhöz anonim, önkitöltős kérdőívet alkalmaztunk, $94 \mathrm{db}$, többségében zárt végú kérdéssel. A felmérés eszköze a Klinikai Interkulturális Kompetencia Kérdőív (KIK-kérdőív, Clinical Cultural Competency Questionnaire) magyarra fordított és adaptált verziója volt. A felmérés kérdései 6 témakör köré csoportosultak: szociodemográfiai jellemzők; többségi populációtól eltérő kultúrájú csoportok egészségügyi ellátásával kapcsolatos háttérismeretek; attitűdök és készségek; komfortérzet kultúrközi szituációkban; a felsorolt témákkal kapcsolatos korábbi képzéseken való részvétel; illetve a jövőbeni képzéseken való részvételi szándék. Az adatok feldolgozása SPSS 21.0 programcsomaggal történt.

Eredmények: Az eredmények alapján megállapíthatjuk, hogy a kérdőív által vizsgált 4 fő kérdéskör esetében (ismeretek, készségek, attitűdök és komfortérzet kultúrközi szituációkban) a magasabb nyelvi kompetenciák, azaz a több idegen nyelv ismerete minden szempontból növelték az interkulturális kompetenciaszintet. A korábban elvégzett interkulturális képzési programok egyedül az ismeretek magasabb szintjével álltak összefüggésben, de nem voltak hatással a résztvevők készségeire, attitűdjeire és kultúrközi szituációkban való komfortérzetére. Számos specifikus, fejlesztendő területet azonosítottunk, mint például a kulturálisan szenzitív életvégi ellátást, valamint a munkatársak, páciensek derogáló megjegyzéseivel szembeni megküzdést. 
Következtetések: Annak ellenére, hogy nehézséget jelenthet egy új kurzus kurrikulumba integrálása a hallgatók túlterheltsége és időhiánya miatt, a hallgatók nyitottak további ismeretek elsajátítása és készségfejlesztés iránt a migrációs kérdéskör aktualitása miatt, valamint saját ismereteik, készségeik fejlődésének érdekében. Bízunk abban, hogy eredményeinkre és hallgatóink javaslataira alapozva a közeljövőben egy sikeres, új klinikai interkulturális kompetencia kurzust indíthatunk.

Kulcsszavak: interkulturális kompetencia; orvosképzés; migráns; etnikai kisebbség; egészségegyenlőtlenség

\section{Summary:}

Background: Since 2013 the rapidly growing international migration has posed new challenges to EU healthcare systems. As a result of the crisis situation caused by mass immigration in 2015 a 'High-level meeting on Refugee and Migrant Health' was organised by World Health Organization (WHO) and its Outcome Document emphasizes the importance of providing migrantsensitive health care and training health professionals taking into account the migrants' cultural, religious, and linguistic diversity. Along these recommendations this study aims to assess medical students' preparedness, and actual level of intercultural competence (ICC), and to identify potential deficiencies and areas to be improved.

Methods: A questionnaire survey was conducted at University of Pécs, in 2016/17 study year among freshmen and senior medical students. A total of 391 questionnaire were analysed and the response rate was $83.9 \%$. Anonymous, self-administered questionnaire was used containing 94, mainly close-ended items. The tool was a modified and translated version of 'Clinical Cultural Competence Questionnaire' developed by R.C. Like. The items were grouped into 6 sections: sociodemographic characteristics, knowledge, skills, attitudes in relation to providing healthcare for culturally diverse populations and comfort-level in intercultural situations, and previously completed ICC trainings, as well as willingness to attend future diversity trainings. Data were analysed using SPSS 21.0.

Results: Based on our results, higher scores were demonstrated in terms of 'better language competencies' (ie. the more foreign languages spoken) for all of the 4 main ICC domains, while 'previous intercultural trainings' were only related to higher level of 'Knowledge' but had no effect on participants' 'Skills', 'Attitudes' and 'Comfort-level'. Our study highlighted some specific sensitive areas to improve, such as 'providing culturally-sensitive end-life care' or 'dealing with derogatory remarks on somenone's ethnicity'.

Conclusions: Despite intergrating a new course into medical curriculum may face several difficulties due to students' overload and lack of time, still, it is encouraging that study participants are open towards further information. We hope that our study results and the consideration of participants' proposals will surely contribute to the success of a new optional ICC course in the close future.

Keywords: intercultural competence; medical education; migrant; ethnic minority; health disparities

\section{BEVEZETÉS}

2013 első félévétől kezdődően korábban soha nem látott mértékű menekültáradat érte el Európát, amely váratlan kihívások elé állította mind a tranzit(többek közt Magyarország), mind az európai uniós célországok egészségügyi ellátórendszereit és szakembereit. A 2015-ös menekültválság hívta életre a "Menekültek és migránsok egészsége" WHO-csúcstalálkozót (High-level meeting on Refugee and Migrant Health), melynek záródokumentuma több pontban is (2.3. és 2.4.) felhívja 
a tagországok figyelmét az ún. „migránsérzékeny” egészségügyi ellátórendszer kialakításának fontosságára, az egészségügyi ellátórendszer és az egészségügyi személyzet alkalmasságának, valamint felkészültségének rendszeres monitorozására, továbbá kapacitásának megerősítésére és továbbfejlesztésre. ${ }^{1}$ A dokumentum egy külön pontban (2.9.) rámutat annak fontosságára, hogy olyan egészségügyi ellátórendszerekre van szükség, amelyek képesek alkalmazkodni és megfelelő választ adni a folytonosan változó összetételű bevándorló- és más migránspopulációk szükségleteire, valamint figyelembe veszi a kulturális, vallási és nyelvi sokszínúséget.' Ennek érdekében elengedhetetlen a menekültekkel és a bevándorlókkal foglalkozó szakemberek képzése és továbbképzése. ${ }^{1}$ Az utóbbi évek nemzetközi tudományos szakirodalmában egyre több közlemény hívja fel a figyelmet a klinikai interkulturális kompetenciák szerepére a menekültek, és más, a többségi társadalomtól eltérő kulturális háttérrel rendelkező populációk egészségügyi ellátásában, valamint hangsúlyozza az egészségügyben dolgozók ilyen irányú képzésének szükségességét. ${ }^{2,3,4,5} \mathrm{~A}$ klinikai interkulturális kompetencia-képzések igazoltan javítják az egészségügyi dolgozók ismereteit, attitúdjeit és készségeit, valamint az ellátásban részesülők elégedettségét, ugyanakkor, jelen ismereteink szerint közvetlenül nem bizonyítható ezen képzések pozitív hatása a kliensek egészségére, legfeljebb valószínűsíthető. $5,6,7,8$

Bár hazánk a migráció szempontjából elsődlegesen nem célország, azonban a 2015-ös krízishelyzethez hasonló szituációk felkészült egészségügyi személyzetet kívánnak, ezt igazolják kutatócsoportunk, a PTE-ÁOK, Műveleti Medicina Tanszék, Migrációsegészségügyi Tanszéki Csoportja által, 2016 tavaszán végzett felmérés tapasztalatai is. A 2015-ös évben - a 2012-t megelőző, évenkénti 1-2 ezer benyújtott kérelemhez képest - több, mint 177 ezer menedékjog iránti kérelmet nyújtottak be hazánkban a Bevándorlási és Állampolgársági Hivatalhoz (BÁH). A fókuszcsoportos felmérést a 2015-ös krízis során, a menedékkérők egészségügyi ellátásában részt vett szakemberek (állami ellátásban dolgozó és önkéntes orvosok, BÁH-dolgozók, stb.) körében végeztük. Ennek a felmérésnek az egyik legfontosabb konklúziója szintén az volt, hogy égető szükség lenne a menedékkérők megfelelő egészségügyi ellátásához az egészségügyi dolgozók klinikai interkulturális kompetenciáinak fejlesztésére, ismereteik bővítésére; pl. eredetország-specifikus ismeretekre, beleértve a migráció szempontjából „küldő” országokra jellemző közegészségügyi-, járványügyi helyzetet, valamint az adott népcsoportra jellemző, egészséget és egészségügyi ellátást meghatározó vallási, kulturális ismereteket is.

Legjobb tudomásunk szerint, még nem született a Magyarországon tartózkodó menedékkérők, bevándorlók, ideiglenes tartózkodási vagy letelepedési engedéllyel rendelkezők, valamint ideiglenes és tartós munkavállalók, etnikai kisebbségek, illetve más vallási vagy kulturális hátterű csoportok egészségügyi ellátásával kapcsolatos klinikai interkulturális kompetencia-felmérés, továbbá, a hazai tudományos szakirodalomban nem született a betegellátást és orvosképzést klinikai interkulturális szempontból vizsgáló közlemény. Ezen a területen magyar nyelvû cikkek és tanulmányok elsősorban a Magyarországon élő roma kisebbség egészségi állapotával, valamint a roma kultúra egészségre gyakorolt hatásával kapcsolatosan születtek (pl. egészségmagatartás, orvoshoz fordulási szokások), valamint a közelmúltban látott napvilágot egy, a hazánkban tanuló külföldi orvostanhallgatók beilleszkedésével (akkulturációjával) kapcsolatos közlemény. ${ }^{9,10,11}$ Jelenleg a PTE-ÁOK képzési palettáján a migránsok és etnikai, vallási kisebbségek ellátásával kapcsolatos klinikai interkulturális kompetenciák fejlesztése még nem teljesen kurrikulumba integrált. Néhány választható kurzus már a hallgatók rendelkezésére áll, melyek célja a kisebbségek iránti érzékenyítés és a tolerancia erősítése, illetve az interkulturális kommunikációs készségek, attitűdök fejlesztése (magyarul az „interkulturális kommunikáció az orvostudományban", valamint a német nyelvű képzésen „interkulturelle Kommunikation in Gesundheitsberufen"; illetve angol képzési nyelven az „intercultural competence in doctor-patient communication").

\footnotetext{
' A cikkben migráns gyújtőfogalom alatt értjük a hazánkban jogszerútlenül tartózkodó irreguláris migránsokat, továbbá a menedékkérőket és elismert státusszal rendelkezőket (menedékes, oltalmazott, menekült vagy befogadott), valamint a hosszabb-rövidebb ideig Magyarországon élő, tartózkodási és/vagy letelepedési engedéllyel rendelkező bevándorlókat és más külföldi állampolgárokat (diplomaták, külföldi vendéghallgatók és munkavállalók, stb.). További információ: www.iom.int/key-migration-terms
} 
Jelen vizsgálat és tanulmány célkitǔzéseit a WHO előzőekben idézett ajánlásaival és törekvéseivel összhangban határoztuk meg, szem előtt tartva az egészségügyi dolgozók, elsősorban a leendő orvosok alkalmasságának és felkészültségének rendszeres monitorozását, és szükség szerinti továbbfejlesztését. Ezek alapján kutatásaink során kérdőíves módszerrel felmértük a tanulmányaikat éppen megkezdő 1., valamint a már klinikai tapasztalattal is rendelkező 4. és 5. évfolyamos, magyar nyelvû képzési programban tanuló orvostanhallgatók klinikai interkulturális kompetenciájának jelenlegi szintjét. Vizsgáltuk, hogy leendő orvosaink mennyire felkészültek a multikulturális környezetben való munkavégzésre; milyen ismeretekkel, attitűdökkel és készségekkel rendelkeznek a bevándorlók, menekültek, illetve etnikai és vallási kisebbségek egészségében, illetve egészségügyi ellátásában mutatkozó egyenlőtlenségek és speciális szükségletek témájában. Vizsgáltuk, hogy kezdeti klinikai tapasztalataik alapján miként értékelik komfortszintjüket klinikai interkulturális szituációkban (pl. vallási szükségletek figyelembevétele, derogáló megjegyzések, nagyszámú rokonság megjelenése az ellátás során, stb.). Kérdőívünk segítségével kívántuk feltárni az esetleges hiányosságokat az említett 4 fő kérdéskör esetén (ismeretek, készségek, attitűdök és komfortszint). Végül célunk volt, hogy képet kapjunk az orvostanhallgatók interkulturális kompetenciák témában szerzett korábbi képzéseiről, illetve önképzési formáiról, valamint adatokat gyújtsünk a hallgatók igényeiről, szükségleteiről, képzési javaslatairól. Eredményeink egyes szociodemográfiai mutatók mentén való összehasonlítása azt a célt szolgálta, hogy feltárjuk a fentebb részletezett témákban az esetleges különbségeket, és megpróbáljunk választ adni azok okaira, hátterére (pl. nem, életkor, nyelvismeret, stb.).

\section{MÓDSZEREK}

\section{A felmérés alanyai}

Kérdőíves felmérésünket a PTE-ÁOK általános orvos szakán, a magyar nyelvű képzési programban részt vevő 1., valamint 4. és 5. évfolyamot végző hallgatók körében végeztük el a 2016-2017-es tanév során. A felmérés technikai lebonyolításában a PTE Orvosi
Népegészségtani Intézete nyújtott támogatást, a kérdőíveket az intézetvezető engedélyével, közegészségtan gyakorlati órák keretein belül töltettük ki a hallgatókkal. A hallgatók előzetes szóbeli tájékoztatást kaptak és a részvételben való beleegyezését követően, az órák elején körülbelül 15 perc állt rendelkezésükre, hogy a kérdőíveket kitöltsék, melyeket utána zárt borítékban gyűjtöttünk össze. A hallgatók kutatásban való részvétele önkéntes és ellenszolgáltatás nélküli volt.

A hallgatói létszám meghatározásához az adott évfolyamra beiratkozott teljes hallgatói létszámot vettük alapul, így összesen 466 hallgatót kívántunk felmérésünkbe bevonni. A felmérés időszakában 71 fő nem töltött ki kérdőívet (hiányzás miatt, vagy nem kívánt részt venni a kutatásban), valamint további 4 főt kizártunk az analízisből (nem töltötte ki a nemre, és/vagy a korra vonatkozó kérdéseket), így a végső analízis során összesen 391 kérdőívet értékeltünk, tehát a válaszadói ráta 83,9\%-os volt.

\section{A kérdőíves módszer}

Felmérésünkhöz anonim, önkitöltős kérdőívet alkalmaztunk $94 \mathrm{db}$, többségében zárt végű kérdéssel. A felmérés eszköze a Like (a New Brunswick-i Rutgers Robert Wood Johnson Medical School családorvostani intézetének vezető professzora) által kifejlesztett Klinikai Interkulturális Kompetencia Kérdőív (KIK-kérdőív, Clinical Cultural Competency Questionnaire) volt. ${ }^{12}$ A teszt szerzőjének hozzájárulásával történt a kérdőívek magyar nyelvre való lefordítása, továbbá egyes kérdések hazai viszonyokra adaptálása, valamint a kérdőív 14 kérdéssel történő kiegészítése. Az adaptált és kiegészített kérdőíveken lábjegyzetben jelöltük, hogy melyek azok a kérdések, amelyek nem voltak az eredeti, KIK-kérdőív részei, és a címlapon lábjegyzetben hivatkoztunk az eredeti kérdőívre is.

A felmérés 6 fő kérdéskört ölelt fel, ezek a szociodemográfiai sajátosságok és a klinikai interkulturális kompetencia 4 fő szempontja: a háttérismeretek, készségek, komfortérzet kultúrközi szituációkban, valamint attitǔdök. [1. táblázat] A hatodik kérdéskör a korábbi kultúraközi oktatásban való részvételre, valamint a jövőbeni képzések iránti érdeklődésre, nyitottságra vonatkoztak. A válaszok többségét 5 fokozatú Likert-skálán kellett a válaszadóknak jelölniük (1=„egyáltalán nem”, 2=„inkább nem”, 
3=„,közepes”, 4=„,többnyire”, 5=„,nagyon”). Egyéni válaszokat adni csak a szociodemográfiai szekcióban, illetve a képzésekkel kapcsolatos szekcióban lehetett összesen 15 kérdésre.

$A z$ „A szekció” 9 kérdése a résztvevők szociodemográfiai jellemzőire irányult (pl. nem, kor, beszélt nyelvek, külföldön töltött idő, stb.). A „B szekció” 21 kérdésből állt és a különböző etnikai csoportok egészségi állapotában mutatkozó egyenlőtlenségek, valamint más, klinikai interkulturális témákkal kapcsolatos ismereteiket (pl. etnofarmakológia, tradicionális gyógymódok, stb.) kellett a kitöltőknek 1-től 5-ig terjedő skálán értékelniük. Ebben a szekcióban az eredeti KIK-kérdőívet 5 kérdéssel egészítettük ki, melyek a hallgatók romák ellátásával kapcsolatos, valamint migráció-egészségügyi ismereteire vonatkoztak (pl. migránsok ellátáshoz való hozzáférésének akadályai, speciális egészségi kockázataik, stb.). Az egyes kérdésekre adott válaszokat „Ismeretek” pontértékké összesítettük, melynek értéke 21-től 105-ig terjedő skálán helyezkedett el a vizsgált változók függvényében. A "C szekcióban” 15 kérdés vonatkozott a válaszadók szociokulturális helyzetekben való készségeinek önértékelésére, mint például „kulturálisan megfelelő fizikai vizsgálat”, vagy ",betegoktatás végzése", stb. A legmagasabb pontérték ebben a szekcióban 75 lehetett, a legalacsonyabb pedig 15. A „D szekcióban” 16 kérdés vonatkozott a résztvevők „interkulturális helyzetekben vélt vagy tapasztalt komfortérzetére”, „megküzdésére”. Ilyen helyzet lehet például olyan betegek gyógyítása, akik ragaszkodnak az alternatív, vagy népi gyógyászati módszerek alkalmazásához, vagy a fájdalom kulturálisan különböző megnyilvánulásainak kezelése az ellátás során, illetve az ellátást végzőknek a „derogáló, diszkriminatív megjegyzésekkel való megküzdése” az ellátás során mind a saját, mind a kollégáik, mind pedig más betegek irányában. Az összesített pontérték ezen kérdéskör esetében 16-80 között lehetett. Az „E szekciónak” („Attitűdök” kérdéskör) 3 alszekciója volt: 12 kérdés vonatkozott az egészségegyenlőtlenségeket meghatározó tényezők szerepére, 5 kérdés a jövőbeni munkavégzés során előforduló szociokulturális helyzetek jelentőségére, 3 kérdés pedig a válaszadó saját etnikai identitásának, és előítéleteinek felismerésére. Az „Attitűdök” kérdéskör összesített pontértékei 20-tól 100-ig terjedő skálán helyezkedtek el. Az utolsó, „F szekció” kérdései az interkulturális kompetencia-képzésre vonatkoztak: pl. korábbi képzéseken való részvételre, az egészségügyi dolgozók interkulturális kompetenciaképzésének fontosságára (1-től 5-ig terjedő skála), továbbá válaszadóink „igen”, „nem” és „talán” válaszlehetőségekkel jelölték saját érdeklődésüket és esetleges részvételi szándékukat egy klinikai interkulturális kompetenciák fejlesztését célzó jövőbeni választható kurzuson. Végül 2 nyitott kérdés során vizsgáltuk a hallgatók véleményét az interkulturális kompetenciák kurzus orvosképzésbe integrálásának nehézségeiről és felmértük javaslataikat.

1. táblázat: A felméréshez használt kérdőiv témái, fő szekciói, kérdéskörei

\begin{tabular}{|c|l|c|}
\hline Szekció & \multicolumn{1}{|c|}{ Kérdések fókusza (önértékelés) } & Kérdések száma \\
\hline A & Szociodemográfiai jellemzők & 9 \\
\hline B & Ismeretek az egészség-/egészségügyi egyenlőtlenségekről & 21 \\
\hline C & Készségek az eltérő szociokulturális hátterü betegek ellátásában & 15 \\
\hline D & Komfortszint szociokulturális felkészültséget igénylő helyzetekben & 16 \\
\hline E & I. Attitűdök az egyenlőtlenségekhez vezető tényezők szerepének értékelése & 17 \\
\hline & II. Önismeret, tudatosság az alábbi területeken: & 1 \\
\hline & a. saját etnikai, kulturális identitás & 1 \\
\hline & b. etnikai, kulturális sztereotípiák & 1 \\
\hline & c. etnikai, kulturális elfogultság, előítéletek & 1 \\
\hline F & III. Kulturális kompetencia-képzés fontosságának értékelése & 8 \\
\hline & I. Korábbi képzések, tanulmányok kulturális sokszínűség témakörében & 2 \\
\hline & II. Érdeklődés és szándék kulturális kompetenciát fejlesztő kurzus iránt & 2 \\
\hline & III. Interkulturális kompetenciát fejlesztő kurzus orvosképzésbe integrálásának kihívásai \\
\hline
\end{tabular}

Forrás: saját szerkesztés 
Statisztikai analízis

Az adatok statisztikai feldolgozása SPSS 21.0 programcsomaggal történt. Minden változó esetében leíró statisztikai elemzések és gyakorisági táblázatok készültek. A nominális változók esetében Pearson-féle khi-négyzet próbát végeztünk, míg a sorrendi változók összehasonlítására MannWhitney-teszt és Kruskal-Wallais-teszt készült. A sorrendi változók közötti összefüggések erősségének vizsgálatára Pearson-féle korrelációs együtthatót (r) számoltunk. Az értékelésnél a 95\%-os megbízhatósági tartomány alkalmazása mellett a p<0,05 eredményt tekintettük szignifikánsnak.

\section{EREDMÉNYEK}

A vizsgált populáció szociodemográfiai jellemzői

A kutatásba bevont 391 fő szociodemográfiai adatait a 2. táblázat mutatja. Az eredmények könynyebb interpretálása érdekében a kutatás kezdetén két jól elkülöníthető célcsoportot határoztunk meg: a tanulmányaikat éppen csak megkezdő elsőéves (192 fő), valamint már klinikai gyakorlati tapasztalatokkal is rendelkező felsőbb éves (4-5. évfolyamot végző) hallgatók kérdőíveinek összevont csoportja (összesen 199 fő).

2. táblázat: A felmérésben résztvevők szociodemográfiai adatai

\begin{tabular}{|c|c|c|c|c|c|c|c|}
\hline & \multicolumn{2}{|c|}{$\begin{array}{c}\text { ÖSSZESEN } \\
\left(N^{\prime}=466\right)\end{array}$} & \multicolumn{2}{|c|}{$\begin{array}{l}\text { 1. évfolyam } \\
\text { hallgatói } \\
\left(N^{\prime}=207\right)\end{array}$} & \multicolumn{2}{|c|}{$\begin{array}{l}\text { 4-5. évfolyam } \\
\text { hallgatói } \\
\left(N^{\prime}=259\right)\end{array}$} & \multirow[t]{2}{*}{ p-érték } \\
\hline & $\mathrm{N}$ & $\%$ & $\mathrm{~N}$ & $\%$ & $\mathrm{~N}$ & $\%$ & \\
\hline Válaszadók száma/válaszadói ráta & 391 & 83,9 & 192 & 92,8 & 199 & 76,8 & \\
\hline \multicolumn{8}{|l|}{ Nemek szerint } \\
\hline Férfi & 149 & 38,1 & 77 & 40,1 & 72 & 36,2 & \multirow{2}{*}{0,425} \\
\hline Nő & 242 & 61,9 & 115 & 59,9 & 127 & 63,8 & \\
\hline \multicolumn{8}{|l|}{ Életkor szerint } \\
\hline 20 év alatt & 100 & 25,6 & 100 & 52,1 & 0 & 0,0 & \\
\hline 21 és 26 év között & 274 & 70,1 & 88 & 45,8 & 186 & 93,5 & \multirow{2}{*}{$<0,001$} \\
\hline 27 év felett & 17 & 4,3 & 4 & 2,1 & 13 & 6,5 & \\
\hline Minimum & 19 & & 19 & & 22 & & \\
\hline Maximum & 29 & & 29 & & 28 & & \\
\hline $\begin{array}{l}\text { Átlag } \\
\text { (Szórás) }\end{array}$ & $\begin{array}{c}22,4 \\
(2,05)\end{array}$ & & $\begin{array}{c}20,8 \\
(1,44)\end{array}$ & & $\begin{array}{c}23,9 \\
(1,15)\end{array}$ & & \\
\hline \multicolumn{8}{|l|}{ Nyelvi kompetenciák, nyelvtudás } \\
\hline Nem beszél idegen nyelven & 6 & 1,5 & 3 & 1,6 & 3 & 1,5 & \multirow{4}{*}{0,760} \\
\hline 1 idegen nyelven beszél & 127 & 32,5 & 67 & 34,9 & 60 & 30,2 & \\
\hline 2 idegen nyelven beszél & 220 & 56,3 & 100 & 52,1 & 120 & 60,3 & \\
\hline 3 vagy több idegen nyelven beszél & 37 & 9,5 & 22 & 11,5 & 15 & 7,5 & \\
\hline \multicolumn{7}{|l|}{ Külföldön tartózkodás } & \multirow{5}{*}{0,730} \\
\hline Soha nem élt külföldön & 276 & 70,6 & 140 & 72,9 & 136 & 68,3 & \\
\hline Legfeljebb 1-6 hónapig élt külföldön & 77 & 19,7 & 25 & 13,0 & 52 & 26,1 & \\
\hline Legfeljebb 1 országban élt minimum fél évig & 24 & 6,1 & 17 & 8,9 & 7 & 3,5 & \\
\hline 2 vagy több országban élt minimum fél évig & 14 & 3,6 & 10 & 5,2 & 4 & 2,0 & \\
\hline
\end{tabular}




\begin{tabular}{|l|l|c|c|c|c|c|c|c|}
\hline \multicolumn{2}{|l|}{ Részesült korábban IKK-képzésben } & & & & & & \\
\hline \\
\cline { 1 - 7 } & Oktatási intézményben & 47 & 12,0 & 28 & 14,6 & 19 & 9,5 & \\
\hline & Oktatási rendszeren kívül & 140 & 35,8 & 71 & 37,0 & 69 & 34,7 & 0,125 \\
\hline \multirow{2}{*}{ Nem részesült sehol } & 221 & 56,5 & 101 & 52,6 & 120 & 60,3 & \\
\hline
\end{tabular}

Forrás: saját szerkesztés

A felmérésben részt vevő orvostanhallgatók közel 2/3-a (62\%) nő, és a két csoport (1. évfolyam, illetve felsőbb évesek) nemek szerinti megoszlása hasonló. [2. táblázat] Koreloszlás tekintetében érthetően szignifikáns különbség mutatkozik a két csoport között, bár a legidősebb hallgató (29 éves) paradox módon éppen 1. évfolyamos volt. A hallgatók közel 2/3-a (65,8\%) legalább 2 idegen nyelven beszél. 71\%-uk nem élt még 1 hónapnál hosszabb ideig külföldön a felmérést megelőzően, és alig 10\% azok aránya, akik több, mint egy országban éltek legalább fél éven át. Interkulturális kompetenciával kapcsolatos témával a résztvevők 12\%-a találkozott korábbi tanulmányai során az iskolarendszeren belül, míg 36\% azok aránya, akik önállóan, az
IKK= interkulturális kompetencia $\mathrm{N}=$ felmérésbe bevont hallgatók száma, N’= válaszadók száma iskolarendszeren kívül (is) gyarapították ezzel kapcsolatos ismereteiket, készségeiket (pl. média, internet, stb.).

A 3. táblázat ismerteti a 4 fő vizsgált kérdéskör öszszesített pontértékeinek átlagát és szórását. Ezek „Ismeretek” az egészségegyenlőtlenségek és más klinikai interkulturális témákban (pl. etnofarmakológia, ellátáshoz való hozzáférés, stb.); "Készségek” önértékelése szociokulturális felkészültséget igénylő helyzetekben; vélt vagy valós „Komfortérzet” interkulturális helyzetekben; végül az „Attitűdök", mint az egyenlőtlenséghez vezető tényezők szerepének, valamint a saját identitás, és sztereotípiák értékelése.

3. táblázat: „Ismeretek”, „Készségek”, „Komfortérzet kultúrközi szituációkban” és „Attitüdök” pontértékei

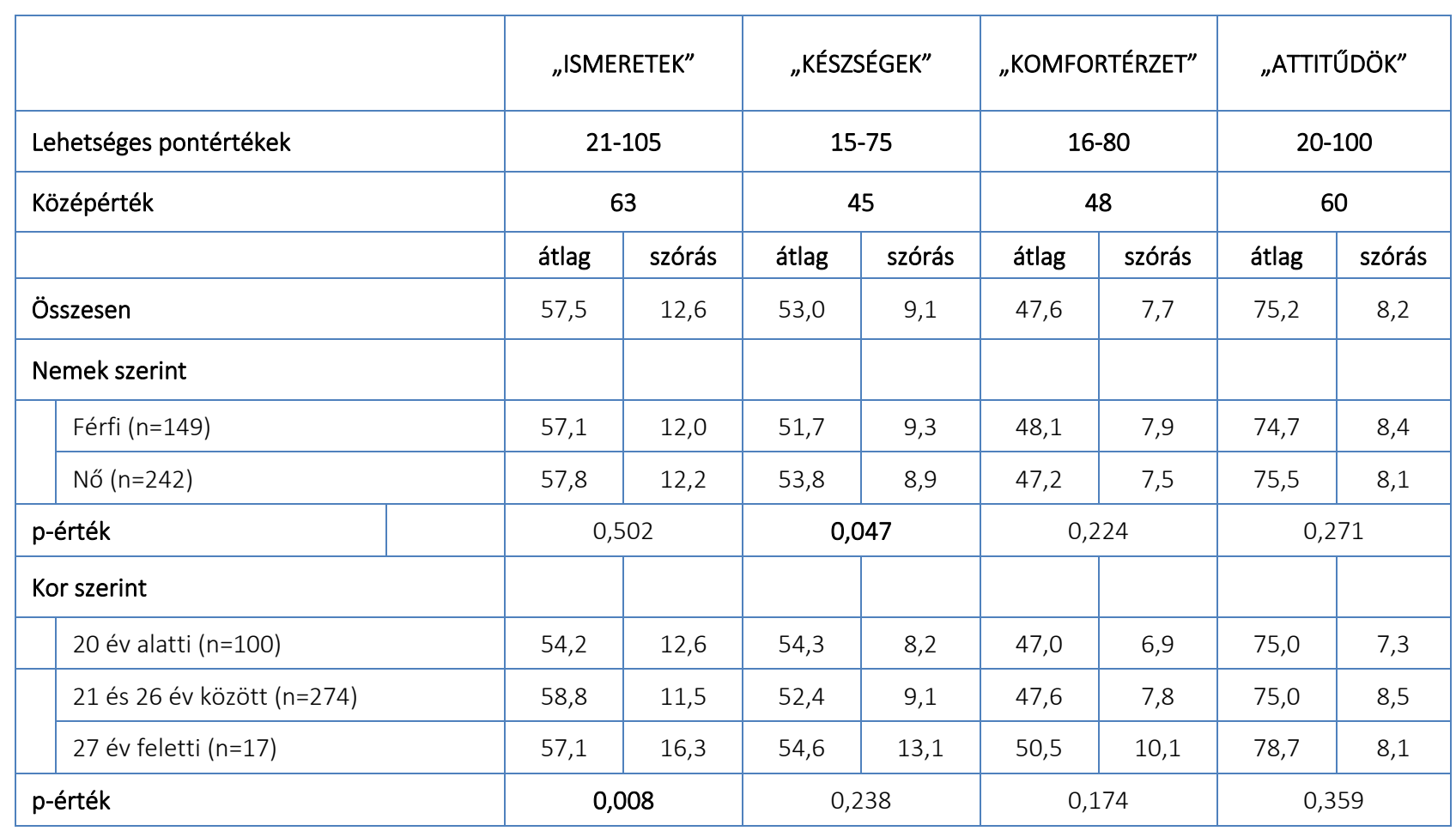




\begin{tabular}{|c|c|c|c|c|c|c|c|c|}
\hline \multicolumn{9}{|l|}{ Évfolyam } \\
\hline 1. évfolyamos $(n=192)$ & 55,7 & 12,0 & 54,1 & 8,8 & 47,9 & 7,4 & 74,5 & 8,5 \\
\hline 4-5. évfolyamos ( $n=199)$ & 59,2 & 12,1 & 51,9 & 9,2 & 47,2 & 8,0 & 76,0 & 7,9 \\
\hline p-érték & \multicolumn{2}{|c|}{0,003} & \multicolumn{2}{|c|}{0,015} & \multicolumn{2}{|c|}{0,313} & \multicolumn{2}{|c|}{0,191} \\
\hline \multicolumn{9}{|l|}{ Nyelvi kompetenciák } \\
\hline Nem beszél idegen nyelveken $(n=6)$ & 58,7 & 7,8 & 50,8 & 7,5 & 44,2 & 5,4 & 69,8 & 5,0 \\
\hline 1 idegen nyelven beszél ( $n=127)$ & 55,6 & 11,7 & 51,0 & 8,5 & 47,1 & 7,3 & 74,6 & 8,0 \\
\hline 2 idegen nyelven beszél $(n=220)$ & 57,9 & 11,5 & 53,5 & 8,9 & 47,3 & 7,4 & 75,3 & 8,0 \\
\hline $\begin{array}{l}3 \text { vagy több idegen nyelven beszél } \\
(n=37)\end{array}$ & 61,7 & 16,3 & 57,4 & 10,8 & 51,2 & 9,6 & 76,5 & 9,5 \\
\hline p-érték & \multicolumn{2}{|c|}{0,012} & \multicolumn{2}{|c|}{0,000} & \multicolumn{2}{|c|}{0,015} & \multicolumn{2}{|c|}{0,074} \\
\hline \multicolumn{9}{|l|}{ Külföldön tartózkodás } \\
\hline Soha nem élt külföldön ( $n=276)$ & 57,1 & 12,1 & 52,2 & 8,7 & 46,4 & 7,4 & 75,1 & 8,2 \\
\hline $\begin{array}{l}\text { Legfeljebb 1-6 hónapig élt külföldön } \\
(\mathrm{n}=77)\end{array}$ & 58,1 & 12,0 & 54,2 & 10,1 & 48,8 & 7,1 & 75,8 & 7,4 \\
\hline $\begin{array}{l}\text { Legfeljebb } 1 \text { országban élt minimum } \\
\text { fél évig }(n=24)\end{array}$ & 60,1 & 14,1 & 55,9 & 8,2 & 52,9 & 8,6 & 75,3 & 9,6 \\
\hline $\begin{array}{l}2 \text { vagy több országban élt minimum } \\
\text { fél évig }(n=14)\end{array}$ & 57,8 & 10,1 & 57,4 & 9,7 & 53,6 & 8,2 & 76,9 & 10,3 \\
\hline p-érték & \multicolumn{2}{|c|}{0,317} & \multicolumn{2}{|c|}{0,003} & \multicolumn{2}{|c|}{0,000} & \multicolumn{2}{|c|}{0,984} \\
\hline \multicolumn{9}{|l|}{ Részesült korábban IKK-képzésben } \\
\hline Oktatási intézményben $(n=47)$ & 59,7 & 13,2 & 53,2 & 9,0 & 47,5 & 7,2 & 76,9 & 9,1 \\
\hline Oktatási rendszeren kívül (n=140) & 60,9 & 12,1 & 54,5 & 9,0 & 48,9 & 8,2 & 75,2 & 8,6 \\
\hline Nem részesült sehol $(n=221)$ & 55,7 & 11,6 & 52,1 & 9,1 & 46,8 & 7,3 & 74,9 & 8,2 \\
\hline p-érték & \multicolumn{2}{|c|}{0,000} & \multicolumn{2}{|c|}{0,145} & \multicolumn{2}{|c|}{0,079} & \multicolumn{2}{|c|}{0,227} \\
\hline
\end{tabular}

Forrás: saját szerkesztés

IKK= interkulturális kompetencia $\mathrm{n}=$ válaszadók száma adott kategórián belül

Nemek szerint értékelve megfigyelhető, hogy a nők körében szignifikánsan magasabb a „készségek” kérdéskör összesített pontértéke, míg a magasabb életkorral, illetve képzési évvel összefüggésben egyaránt magasabb az "ismeretek” kérdéskör összesített pontértéke. A tanulmányaikat megkezdő 1. éves hallgatók magasabbra értékelték ",készségeiket" is, bár életkor szerint nézve ez az eredmény nem kapott megerősítést.

Jobb nyelvi kompetenciák mind a 4 vizsgált kérdéskör tekintetében arányosan magasabb pontértékkel járnak együtt, az összefüggés az „attitűdök” kérdéskör kivételével szignifikáns, bár a pozitív tendencia ott is megfigyelhető.

A „több országban élés” változó szignifikánsan magasabb pontértékeket mutat a "készségek” illetve „komfortérzet kultúrközi szituációkban” kérdéskörök esetén, viszont nem mutat összefüggést sem az „ismeretek”, sem az „attitűdök” tekintetében. A felmérést megelőző, interkulturális témakörben végzett tanulmányok, mind az iskolarendszerben, mind azon kívül, magasabb „ "ismeretek” pontértékeket eredményez, de nem mutat összefüggést a jobb "készségekkel”, „komfortérzettel”, vagy pozitívabb „attitüdökkel”. 
Egészségügyi dolgozók interkulturális képzésének fontossága

A felmérésben részt vevő hallgatók 1-től 5-ig terjedő skálán értékelték az egészségügyi dolgozók interkulturális kompetencia-képzésének fontosságát. Az átlagérték 3,92 volt, és a női résztvevők fontosabbnak tartják az egészségügyi dolgozók ezen kompetenciáinak fejlesztését (4,07, míg a férfiak
3,67; $p<0,001)$. Hasonlóképpen, az 1. évfolyamos hallgatók és azok, akik a felmérést megelőzően is részt vettek interkulturális kompetencia-képzésen, vagy akár egyénileg informálódtak a témával kapcsolatosan, nagyobb jelentőséget tulajdonítanak az ilyen képzéseknek, mint azok, akik korábban nem tanultak, vagy tájékozódtak e témában $(p<0,005)$. [4. táblázat]

4. táblázat: Egészségügyi dolgozók klinikai interkulturális képzésének fontossága

\begin{tabular}{|c|c|c|c|c|c|c|c|c|}
\hline & \multirow{2}{*}{\multicolumn{2}{|c|}{$\begin{array}{c}\text { Fontosnak tartja } \\
\text { az egészségügyi } \\
\text { dolgozók } \\
\text { IKK-képzését }\end{array}$}} & \multicolumn{3}{|c|}{$\begin{array}{c}\text { Érdekelné klinikai interkulturá- } \\
\text { lis kompetenciáit fejlesztő } \\
\text { kurzus }\end{array}$} & \multicolumn{3}{|c|}{$\begin{array}{c}\text { Szívesen részt venne klinikai } \\
\text { interkulturális kompetenciáit } \\
\text { fejlesztő kurzuson }\end{array}$} \\
\hline & & & \multirow{2}{*}{$\begin{array}{c}\begin{array}{c}\text { Igen } \\
(n=219)\end{array} \\
\%\end{array}$} & \multirow{2}{*}{$\begin{array}{c}\begin{array}{c}\text { Talán } \\
(\mathrm{n}=97)\end{array} \\
\%\end{array}$} & \multirow{2}{*}{$\frac{\underset{N}{N e m}}{(n=75)}$} & \multirow{2}{*}{$\begin{array}{c}\begin{array}{c}\text { Igen } \\
(n=196)\end{array} \\
\%\end{array}$} & \multirow{2}{*}{$\begin{array}{c}\begin{array}{c}\text { Talán } \\
(\mathrm{n}=112)\end{array} \\
\%\end{array}$} & \multirow{2}{*}{$\begin{array}{c}\begin{array}{r}\text { Nem } \\
(n=83\end{array} \\
\%\end{array}$} \\
\hline & átlag & szórás & & & & & & \\
\hline ÖSSZES HALLGATÓ (N=391) & 3,9 & 1,1 & 56,1 & 24,8 & 19,2 & 50,1 & 28,6 & 21,2 \\
\hline \multicolumn{9}{|l|}{ Nemek szerint } \\
\hline Férfi (n=149) & 3,7 & 1,1 & 49,0 & 26,2 & 24,8 & 41,6 & 30,9 & 27,5 \\
\hline Nő $(n=242)$ & 4,1 & 0,9 & 60,3 & 24,0 & 15,7 & 55,4 & 27,3 & 17,4 \\
\hline p-érték & \multicolumn{2}{|c|}{0,001} & \multicolumn{3}{|c|}{0,014} & \multicolumn{3}{|c|}{0,004} \\
\hline \multicolumn{9}{|l|}{ Kor szerint } \\
\hline 20 év alatti $(n=100)$ & 4,0 & 1,0 & 53,0 & 33,0 & 14,0 & 48,0 & 34,0 & 18,0 \\
\hline 21 és 26 év között ( $n=274)$ & 3,9 & 1,0 & 55,8 & 22,6 & 21,5 & 49,3 & 27,7 & 23,0 \\
\hline 27 év feletti (n=17) & 4,2 & 0,8 & 76,5 & 11,8 & 11,8 & 76,5 & 11,8 & 11,8 \\
\hline p- és r-érték & \multicolumn{2}{|c|}{$0,487(r=-0,35)$} & \multicolumn{3}{|c|}{$0,744(r=-0,017)$} & \multicolumn{3}{|c|}{$0,530(r=-0,032)$} \\
\hline \multicolumn{9}{|l|}{ Évfolyam } \\
\hline 1. évfolyamos (n=192) & 4,1 & 1,0 & 56,8 & 27,6 & 15,6 & 49,5 & 31,8 & 18,8 \\
\hline 4-5. évfolyamos ( $n=199)$ & 4,0 & 1,0 & 55,3 & 22,1 & 22,6 & 50,8 & 25,6 & 23,6 \\
\hline p-érték & \multicolumn{2}{|c|}{0,004} & \multicolumn{3}{|c|}{0,414} & \multicolumn{3}{|c|}{0,791} \\
\hline \multicolumn{9}{|l|}{ Nyelvi kompetenciák } \\
\hline Nem beszél idegen nyelveken $(n=6)$ & 3,7 & 1,2 & 50,0 & 16,7 & 33,3 & 50,0 & 0,0 & 50,0 \\
\hline 1 idegen nyelven beszél $(n=127)$ & 3,9 & 1,1 & 59,1 & 24,4 & 16,5 & 55,9 & 27,6 & 16,5 \\
\hline 2 idegen nyelven beszél $(n=220)$ & 3,9 & 0,9 & 53,6 & 25,9 & 20,5 & 45,6 & 31,4 & 22,7 \\
\hline $\begin{array}{l}3 \text { vagy több idegen nyelven beszél } \\
(n=37)\end{array}$ & 4,1 & 1,1 & 59,5 & 21,6 & 18,9 & 54,1 & 21,6 & 24,3 \\
\hline $\mathrm{p}$ - és r-érték & \multicolumn{2}{|c|}{$0,277(r=0,55)$} & \multicolumn{3}{|c|}{$0,719(r=0,018)$} & \multicolumn{3}{|c|}{$0,337(r=0,049)$} \\
\hline
\end{tabular}




\begin{tabular}{|c|c|c|c|c|c|c|c|c|}
\hline \multicolumn{9}{|l|}{ Külföldön tartózkodás } \\
\hline Soha nem élt külföldön ( $n=276)$ & 3,9 & 1,0 & 56,2 & 24,6 & 19,2 & 50,4 & 28,6 & 21,0 \\
\hline $\begin{array}{l}\text { Legfeljebb 1-6 hónapig élt külföldön } \\
(n=77)\end{array}$ & 3,8 & 0,9 & 54,6 & 24,7 & 20,8 & 46,8 & 28,6 & 24,7 \\
\hline $\begin{array}{l}\text { Legfeljebb } 1 \text { országban élt minimum } \\
\text { fél évig }(n=24)\end{array}$ & 4,1 & 1,0 & 62,5 & 29,2 & 8,3 & 54,2 & 33,3 & 12,5 \\
\hline $\begin{array}{l}2 \text { vagy több országban élt minimum } \\
\text { fél évig }(n=14)\end{array}$ & 3,7 & 1,3 & 50,0 & 21,4 & 28,6 & 57,1 & 21,4 & 21,4 \\
\hline$p$-és r-érték & \multicolumn{2}{|c|}{$0,902(r=-0,006)$} & \multicolumn{3}{|c|}{$0,337(r=0,049)$} & \multicolumn{3}{|c|}{$0,630(r=-0,024)$} \\
\hline \multicolumn{9}{|l|}{ Részesült korábban IKK-képzésben } \\
\hline Oktatási intézményben ( $n=47$ ) & 4,1 & 1,0 & 48,9 & 31,9 & 19,1 & 44,7 & 36,2 & 19,1 \\
\hline Oktatási rendszeren kívül (n=140) & 4,1 & 1,0 & 64,3 & 18,6 & 17,1 & 57,9 & 23,6 & 18,6 \\
\hline Nem részesült sehol $(n=221)$ & 3,8 & 1,0 & 52,0 & 26,7 & 21,3 & 46,6 & 29,4 & 24,0 \\
\hline p-érték & \multicolumn{2}{|c|}{0,003} & \multicolumn{3}{|c|}{0,072} & \multicolumn{3}{|c|}{0,078} \\
\hline
\end{tabular}

Forrás: saját szerkesztés

IKK= interkulturális kompetencia $\mathrm{n}=$ válaszadók száma adott kategórián belül

A kutatásban részt vevők értékelték saját érdeklődésüket és részvételi szándékukat is egy esetleges új, interkulturális kompetenciák fejlesztését célzó, választható kurzuson. Az általános érdeklődés magasnak tekinthető, a válaszadóknak mindössze alig 20\%-a jelezte, hogy őt nem érdekelné egy ilyen kurzus. Nemek szerint vizsgálva a nők nyitottabbak: magasabb érdeklődést és részvételi szándékot mutatnak ( $60,3 \%$ és $55,4 \%$ szemben a férfiak $49,0 \%$ és $41,0 \% ; p<0,05)$. A többi változó esetében nem találtunk szignifikáns összefüggést az érdeklődés illetve részvételi szándék tekintetében.

\section{A kulturális sokszínúség, illetve klinikai interkulturális kompetenciák ismeretének orvosképzésbe integrálásának kihívásai}

Kérdőívünk utolsó 2 nyitott kérdése volt hivatott felmérni válaszadóink véleményét a klinikai interkulturális kompetenciák orvosképzésbe integrálásának esetleges nehézségeiről, és javaslataikról. A hallgatók válaszait tematikusan főbb csoportokba, fókuszpontokba rendeztük. [5. táblázat]

A nehézségek közül legjelentősebbnek a hallgatók által jelzett „időhiány” és a kötelező órák miatti „túlterheltség” bizonyult, és ezzel összefüggésben a javaslataik is elsősorban a kurzus követelményeinek enyhítésével és kötetlen szervezésével kapcsolatosak voltak ( $p l$. ne legyen vizsga, legyen a kurzus fesztelen, interaktív, stb.). További fontos kihívásként a hallgatók „meglévő előítéleteket” és „motivációhiányt" említettek („,nem fontos tárgy”), valamint az oktató felelősségét, kompetenciáit: ne erősítse a sztereotípiákat, legyen objektív, legyen képes priorizálni, tartsa tiszteletben a hallgatók érzéseit, stb.

\section{MEGBESZÉLÉS}

Tanulmányunk ismertetett eredményei betekintést nyújtanak egy korábban alig vizsgált területbe, nevezetesen egy hazai nagyváros orvosi egyetemén (PTE-ÁOK) tanuló hallgatók klinikai interkulturális kompetenciájának: ismereteinek, készségeinek, attitűdjeinek és interkulturális helyzetekben való komfortérzetének hallgatók általi önértékelésébe. Felméréseinket mind a tanulmányaik kezdetén lévő, 1. évfolyamos, mind pedig a már klinikai tapasztalattal rendelkező 4 . és 5 . évfolyamos hallgatók körében is elvégeztük. Megvizsgáltuk, van-e különbség a hallgatói csoportok között a vizsgált kérdéskörök esetében a szerint, hogy a részt vettek-e a képzés során, célzott, klinikai interkulturális kompetenciát fejlesztő kurzuson. Eredményeinket bizonyos 
szociodemográfiai változók mentén (nem, kor, beszélt nyelvek, külföldön töltött idő, korábbi képzéseken való részvétel) is értékeltük, valamint adatokat gyűjtöttünk a hallgatók véleményéről és javaslatairól a klinikai interkulturális kompetenciák kurzus orvosképzésbe integrálásának nehézségeivel és lehetőségeivel kapcsolatosan.

A két meghatározott hallgatói célcsoportunk (1. évfolyamos, illetve 4. és 5. évfolyamos hallgatók) között az életkor volt az egyetlen szignifikáns mértékben eltérő szociodemográfiai változó. [2. táblázat] Eredményeink azt igazolták, hogy az idősebb korcsoport (illetve ennek megfelelően a felsőbb éves hallgatók) jobb ismeretekkel rendelkeznek az egészségegyenlőtlenségekkel és más interkulturális témákkal kapcsolatosan. Ez adódhat részben az idősebb életkorral járó, általánosságban szélesebb körű tájékozottságból, érettségből, vagy akár tulajdonítható lehetne a képzés során szerzett ismereteknek. Az utóbbi feltételezés felmérésünknek kedvező, ám a kutatás jelen körülményei között nem igazolható kimenete lenne. Ahhoz, hogy ezt a hipotézist igazolni tudjuk, további felmérésekre van szükség mind kezdő, mind felsőbb éves, medikus és nem medikus hallgatók bevonásával, valamint célzott, klinikai interkulturális kompetenciákat fejlesztő kurzusokon részt vett, illetve részt nem vett hallgatók vizsgálatára.

5. táblázat: A klinikai interkulturális kompetenciák kurzus orvosképzésbe integrálásának kihivásai

\begin{tabular}{|c|c|c|c|}
\hline & KIHÍVÁSOK/NEHÉZSÉGEK & & JAVASLATOK \\
\hline & Fő fókuszpontok & & Fő fókuszpontok \\
\hline 1. & Időhiány, hallgatók túlterheltsége & 1. & $\begin{array}{c}\text { Szervezési, módszertani (interaktivitás, gyakorlat, } \\
\text { kis létszámú csoportok, mérsékelt követelmények } \\
\text { és számonkérés) }\end{array}$ \\
\hline 2. & $\begin{array}{l}\text { Meglévő hallgatói előítéletek (negatív attitűdök, } \\
\text { diszkrimináció, ellentétes vélemények, nézőpontok, } \\
\text { téma túlérzékenysége) }\end{array}$ & 2. & $\begin{array}{l}\text { Tematikus ötletek (miről szóljon a képzés, } \\
\text { pl. testbeszéd, tolerancia, érzékenyítés, } \\
\text { roma kisebbség, témák megfelelő priorizálása) }\end{array}$ \\
\hline 3. & $\begin{array}{c}\text { Oktatói kompetenciák hiánya (pl. stílus, felkészültség, } \\
\text { saját sztereotípiák, konfliktuskezelés képesség, } \\
\text { objektivitás hiánya, stb.) }\end{array}$ & 3. & $\begin{array}{c}\text { Oktatói kompetenciák (személyes példamutatás, } \\
\text { legyen nyitott, objektív, más kultúrából származó } \\
\text { vendégelőadók meghívása) }\end{array}$ \\
\hline 4. & $\begin{array}{l}\text { Hallgató motiváció és érdeklődés hiánya, a téma fontos- } \\
\text { ságának alulértékelése }\end{array}$ & 4. & $\begin{array}{l}\text { Más ötletek (pl. képzés előzetes tesztelése, } \\
\text { egészségügyi szakdolgozók számára is felkínálni, } \\
\text { interkulturális programok szervezése, stb.) }\end{array}$ \\
\hline 5. & $\begin{array}{c}\text { Külső akadályok (információhiány, politikai, financiális, } \\
\text { bürokratikus vagy kollegiális akadályok) }\end{array}$ & & \\
\hline
\end{tabular}

Forrás: saját szerkesztés

Nemek szerint csak a „készségek” kérdéskör esetében találtunk szignifikáns különbséget. [3. táblázat] Hasonlóan Ladson és mtsai felméréséhez, vizsgálatunkban szintén a nők értékelték jobbnak saját készségeiket interkulturális felkészültséget igénylő helyzetekben, ami vélhetőleg a női nem általánosságban érzékenyebb és empatikusabb mivoltának tulajdonítható. ${ }^{13,14}$ Ugyanakkor, esetünkben az 1. évfolyamos hallgatók vélték úgy, hogy könnyebben megbirkóznak az interkulturális felkészültséget igénylő helyzetekkel, szemben ugyanezen témában végzett amerikai tanulmány eredményével, mely szerint a már klinikai tapasztalattal rendelkező felsőbb évesek ítélték jobbnak a készségeiket. ${ }^{13}$ Feltételezhető, hogy a felsőbb éves magyar nyelvű képzésben részesülő hallgatók a klinikai tapasztalatok birtokában, valamint valós interkulturális helyzetek megélését követően kicsit reálisabban és kritikusabban értékelik saját felkészültségüket, mint tanulmányaik kezdetén. 
Felmérésünk egyik fontos eredményének tekintjük, hogy adataink egyértelmúen megerősítik, a jobb nyelvi kompetenciák, a több idegen nyelv ismerete szignifikánsan összefügg és magasabb pontértéket tükröz az interkulturális kompetencia szinte valamennyi vizsgált aspektusa esetében, beleértve mind az „ismeretek”, a „készségek” és a „komfortérzet interkulturális helyzetekben" kérdésköröket egyaránt. Ez az eredmény összhangban áll egy másik amerikai felmérés eredményével, amely az általunk is alkalmazott eredeti kérdőív módosított, adaptált változatával vizsgálta 3. évfolyamos gyógyszerészhallgatók klinikai interkulturális kompetenciaszintjét, és hasonló összefüggést írt le a több nyelv ismerete és a magasabb interkulturális készségek, valamint komfortérzet kérdéskörök esetében. ${ }^{15}$ Ezek az eredmények megerősítik egy 2012-es, 6434 résztvevő bevonásával végzett svájci kutatás eredményeit is, amely szintén összefüggést írt le a nyelvi és interkulturális kompetenciák között. ${ }^{16}$ Érdekes módon, vizsgálatunkban a hosszabb ideig való külföldön élés nem minden kérdéskör esetében igazolt hasonló összefüggést, például nem jár együtt jobb ismeretekkel a migránsok és más kisebbségek egészségegyenlőtlenségével kapcsolatosan, sem pozitívabb attitűdökkel; viszont összefügghet a jobb készségekkel és komfortérzéssel interkulturális helyzetekben $(p<0,05)$. Vélhetően a hosszabb ideig tartó külföldön élés elsődlegesen a komfortszintet, valamint a kommunikációs és más interkulturális készségeket erősíti, de nem feltétlenül jár együtt az adott kultúrákkal kapcsolatos jobb egészségügyi ismeretekkel (pl. egészségegyenlőtlenségek, tradicionális gyógymódok, stb.). Érdemes lenne ezen területen további vizsgálatokat végezni és feltárni az esetleges különbségeket azzal kapcsolatosan is, hogy az interkulturális kompetenciaszintet miként befolyásolja az, hogy a hosszabb ideig külföldön való tartózkodás földrajzilag, illetve kulturálisan milyen mértékben eltérő helyszínen valósult meg (pl. európai, afrikai, vagy közel-keleti országokban, stb.); illetve, hogy milyen okokból történt (pl. magánéleti ok, tanulmányok, munkavégzés egészségügyi vagy nem egészségügyi szektorban, stb.).

Érdemes megfontolni felmérésünk egy másik fontos tanulságát is a jövőbeni, klinikai interkulturális kompetenciát fejlesztő képzések tervezésekor: bár hallgatóink korábbi interkulturális kompetencia tanulmányai (mind iskolarendszerben, mind egyénileg) összefüggést mutattak jobb ismereteikkel, viszont nem eredményeztek jobb készségeket, pozitívabb attitüdöket vagy magasabb komfortszintet kultúraközi helyzetekben. Ezt megerősítendő, egy kvalitatív amerikai tanulmány is azt írta le, hogy a kurrikulumba integrált klinikai interkulturális kompetencia tananyagtartalmak ugyan növelték a medikus hallgatók ismereteit, de nem bizonyultak hatékonynak a specifikus klinikai interkulturális készségek fejlesztésében. ${ }^{17}$ Ezért rendkívül fontos, hogy olyan képzési programokat tervezzünk, amelyek változatos, interaktív módszerek alkalmazásával különös hangsúlyt fektetnek a készségek fejlesztésére és az attitűdformálásra. Egy eredményes kurzus előkészítése érdekében mindenképpen érdemes már a program előkészítése során felmérni és figyelembe venni a hallgatói igényeket, aggályokat, javaslatokat is. [5. táblázat]

Ha az eredményeinket nem csak kérdéskörönként, összegzett pontértékek alapján elemezzük (pl. ismeretek, készségek, stb.), hanem azokon belül, kérdésenként is vizsgáljuk, az további fontos részletekre is ráirányíthatja a figyelmet: például az ún. gyengeségekre, a legalacsonyabb pontokkal értékelt kérdésekre, a különösen fejlesztendő területekre. Ilyen témák például az „ismeretek” kérdéskörön belül az „etnofarmakológia”, „a különböző tradicionális gyógymódok” vagy például a „menekültek ellátáshoz való hozzáférésének” témakörei. A „készségek” kérdéskörön belüli legalacsonyabb pontértéket a „kulturálisan érzékeny életvégi ellátás nyújtása” kapta. A legkevésbé komfortos helyzetek hallgatóink számára azok, amelyek során "derogáló megjegyzésekkel” szembesülnek, akár saját maguk, akár mások (kollégák, kliensek) etnikai hátterével kapcsolatosan, mind a kollégák, mind a kliensek részéről. Az ezzel kapcsolatos kérdések a legalacsonyabb "komfortszint” pontértékeket kapták (mindhárom kérdés esetében az átlag 2,08 alatt volt, holott az átlagérték a „komfortszint” kérdéskör esetében 1-től 5-ig terjedő skálára vetítve 2,97 volt). Fontos tehát ezekre a részterületekre is nagyobb hangsúlyt helyezni, és mind jobban beépíteni az orvosi kurrikulumba, hogy miként fejleszthetjük a hallgatók megküzdési stratégiáit, ha esetleg diszkriminatív megnyilvánulásokkal szembesülnek az ellátás során. Hasonlóképpen, felkészíteni őket a kulturálisan szenzitív életvégi ellátás nyújtására, bár tudvalévő, hogy az életvégi ellátás sokak számára 
önmagában, hasonló etnikai, vagy kulturális hátterú betegek, illetve családjaik számára is megterhelő terület.

A releváns tudományos szakirodalom jelentős része hangsúlyozza a klinikai interkulturális kompetencia tartalmak orvosképzésbe integrálásának fontosságát, és számos közlemény vizsgálja a kulturális kompetencia képzési programok hatásait a résztvevők ismereteire, készségeire és attitúdjeire. ${ }^{2,3,4,13,15,18,19}$ Bár egyelőre tudományosan nem igazolt, de számos elismert szerző és kutatócsoport valószínúsíti, hogy az egészségügyi dolgozók fejlődő klinikai interkulturális kompetenciái közvetve pozitív hatással bírnak a betegek egészségmutatóira is. ${ }^{6,7}$ Mindazonáltal, a klinikai interkulturális kompetencia képzési programok fő célja, hogy specifikus ismeretekkel, készségekkel és eszközökkel vértezze fel az egészségügyi dolgozókat ahhoz, hogy jobban megértsék és kezelni tudják az egészséggel kapcsolatos hiedelmeket, értékeket és változatos magatartásformákat a kulturálisan, illetve etnikailag sokszínú populációk ellátása során. Két fő megközelítés ismert az interkulturális kompetencia képzési programokban. Hagyományosan, az ún. „kategorikus” megközelítés során egyes kulturális csoportokkal kapcsolatos ismereteket, hiedelmeket és magatartásformákat tanítanak a résztvevőknek, és ennél a hagyományos módszernél különösen fontos, hogy az interkulturális képzés alkalmával, az egyes kultúrkörök, etnikai csoportok tárgyalása során kerüljük a sztereotipizálást. Az újabb, az ún. kultúrákon átívelő (crosscultural) megközelítés inkább a kommunikáció folyamatára és bizonyos közös kulturális és szociális tényezőkre fókuszál, olyanokra, amelyek több kultúrában is jelen vannak (pl. kirekesztettség, nemi szerepek, rasszizmus, stb.). ${ }^{2}$ Betancourt és mtsai az interkulturális kompetencia-képzés "legjobb megközelítéseként" a kultúrközi ismeretek és kommunikációs készségek egyensúlyban való oktatását ajánlják, továbbá hangsúlyozzák a betegek szociokulturális hátterének jelentőségét és hatását az orvoskliens interakciókra, döntéshozatalra és ezeken keresztül a kliens egészségi mutatóira. ${ }^{2}$ Koehn és Swick kanadai kutatók tovább szélesítették az interkulturális kompetencia tartalmát és koncepcióját: bevezették az ún. „transznacionális kompetencia” fogalmát. ${ }^{8}$ Tanulmányukban ráirányítják a figyelmet az egészségi állapotban és ellátásban mutatkozó egyenlőtlenségek politikai szintû (szabályozási), szociális, valamint egyéni meghatározottságára is (migrációs okok, háttér, egyéni életesemények, traumák például kínzás, üldöztetés, diszkrimináció, stb.), valamint hangsúlyozzák ezen tartalmak orvosképzésbe integrálását. ${ }^{8}$ Egy németországi és holland kutatócsoport 4 fö témát javasol az orvostanhallgatók klinikai interkulturális képzésére, melyek „epidemiológia: a betegségek epidemiológiájának és terápiákra adott reakcióinak etnikai variációi"; „kultúra, etnicitás és identitás”; „szociális, gazdasági és jogi aspektusok"; valamint „kommunikáció". ${ }^{20}$ Ezen témák összhangban állnak a korábban említett „legjobb megközelítéssel” is. ${ }^{2}$ Tanulmányunk számos szervezési, módszertani és tematikai ajánlást is feltárt a hallgatói igények alapján, mint például a "testbeszéd” egyes formáinak értelmezése a különböző kultúrákban, más kultúrából származó vendégoktatók meghívása, kis létszámú (lehetőség szerint multikulturális) csoportok kialakítása, interaktív oktatásszervezési formák, módszerek alkalmazása, stb. [5. táblázat] A nemzetközi szakirodalomban néhány, már bevezetésre került kurzus, illetve képzési program első tapasztalatai és hallgatói visszajelzései ugyancsak hasznosíthatóak lennének. ${ }^{21,22} \mathrm{Az}$ egyik említett amerikai tanulmány 3. évfolyamos gyógyszerészhallgatók számára indított választható kurzus tapasztalatairól számol be. ${ }^{21}$ A kurzus szervezői - jelen felmérés résztvevőinek javaslatával összhangban - szintén nem alkalmaztak vizsgát a kurzus záró értékeléseként, a hallgatóknak a kurzus teljesítéseként ajánlott irodalmat, esettanulmányokat kellett feldolgozniuk, szimulációs gyakorlatokon vettek részt, valamint irányított vitákon. Ez utóbbi alkalmak során a szerzők rendkívül hasznosnak találták az alacsony csoportlétszámot, amely lehetőséget biztosított arra, hogy a hallgatók jobban megnyíljanak. A kurzus során - ugyancsak hasonlóan jelen felmérés hallgatói ajánlásaihoz -, vendégoktatókat is felkértek órák tartására, akik a különböző közösségekben szerzett gyakorlati tapasztalataikkal gazdagították a tantárgy anyagát. $\mathrm{Az}$ ismertetett kurzussal kapcsolatos hallgatói visszajelzés pozitív volt, és a továbbfejlesztésre tett hallgatói javaslatok szervezésileg további vendégoktatók bevonására, tartalmilag pedig egyes kultúrák részletesebb megismertetésére vonatkoztak. ${ }^{21}$

A klinikai interkulturális kompetencia kurzus orvosképzésbe integrálásának folyamatát számos tényező nehezítheti. A közelmúltban látott napvilágot egy 8 európai klinikát magába foglaló, az 
Európai Unió által finanszírozott projekt („migránsérzékeny kórház", migrant-friendly hospitals) tapasztalatait ismertető közlemény. ${ }^{18} \mathrm{~A}$ projekt során az általunk is alkalmazott KIK-kérdőívvel vizsgálták a résztvevők kompetenciaszintjét, majd képzést nyújtottak számukra, végül vizsgálták a kompetencia egyes kérdésköreinek változásait. Bár tanulmányukban a résztvevők pozitív változásairól számoltak be a klinikai interkulturális ismeretek, készségek és komfortszint tekintetében, azonban feltárták a képzés néhány akadályát is. Ilyen akadályok lehetnek például: a támogatás hiánya a kórház vezetősége részéről, vagy a résztvevők motivációjának a hiánya. Ez utóbbit igazolta az is, hogy főleg ápolók vettek részt a képzésen, az orvosok kevéssé fogadták el annak szükségességét, relevanciáját. Felmerült a készségfejlesztés és a kompetens oktató szükségessége, azonban konklúzióként a szerzők megfogalmazták, hogy gyakorlatilag lehetetlen olyan trénert találni, aki egy személyben minden szükséges területen kompetens: a betegellátás mindennapos gyakorlatában és kihívásaiban, pedagógiában és csoportmoderálásban (pszichoszociológia és konfliktuskezelés), valamint egyidejűleg szakértő a kulturális sokszínűség szerteágazó témakörében is. ${ }^{18}$ Felmérésünk résztvevői hasonló kihívásokat fogalmaztak meg: időhiány, túlterheltség, meglévő sztereotípiák, véleménykülönbségek, motivációhiány, érdektelenség, a téma szerepének alulértékelése, az oktatói kompetenciák szerepe, és külső akadályok, mint pl. a vezetői, kollegiális vagy financiális támogatás hiánya. [5. táblázat] Ahhoz, hogy ezeken az akadályokon átlendüljünk és sikeres, eredményes választható kurzust kínáljunk hallgatóinknak, rendkívül átfogó szakmai háttérkutatásokra, alapos oktatói felkészültségre és nyitottságra van szükség, valamint arra, hogy figyelembe vegyük és megfogadjuk hallgatói felmérésünk tapasztalatait, javaslatait (pl. hiteles vendégoktatók felkérése, limitált csoportlétszám, változatos, interaktív pedagógiai módszerek alkalmazása, lehetőség biztosítása kötetlen vitákra, véleményütköztetésre, felkészülni az esetleges konfliktusok moderálására és mérsékelt, változatos számonkérési formák alkalmazása, stb.). Mindenesetre rendkívül bíztató, hogy hallgatóink többsége (különösen a női válaszadóink, $p<0,05)$ fontosnak tartja az egészségügyi dolgozók klinikai interkulturális kompetenciájának fejlesztését már a képzés során, és válaszadóink túlnyomó része kifejezte érdeklődését és részvételi szándékát egy jövőbeni klinikai interkulturális kompetencia fejlesztését célzó választható kurzuson. [4. táblázat]

\section{KÖVETKEZTETÉSEK}

Az Európai Unió területén, így hazánkban is egyre hangsúlyosabb szerepet kap a bevándorlás témaköre. Bár hazánk a bevándorlás szempontjából inkább tranzit-, mintsem célország, azonban a 2015-ös krízishelyzethez hasonló szituációk, valamint a hazánkban valamilyen okból (pl. tanulás, munkavállalás, stb.) tartósan élő több tízezer külföldi állampolgár és esetlegesen itt tartózkodó családtagjaik kulturálisan adaptált egészségügyi ellátása felkészült egészségügyi személyzetet kíván. Kutatásunk során célul tűztük ki a jövő orvosainak, a jelenlegi orvostanhallgatóknak a menekülteknek, bevándorlóknak és vallási, etnikai kisebbségeknek egészségügyi ellátásával kapcsolatos klinikai interkulturális kompetenciaszintjének, valamint annak fejlesztését célzó kurzus iránti igény felmérését. A felmérésben részt vett orvostanhallgatók száma messze meghaladta a korábbi hasonló vizsgálatba bevontak létszámát, továbbá összehasonlítottuk a képzést megkezdő elsőéves, valamint a már klinikai tapasztalattal rendelkező felsőbb éves hallgatók körében kapott eredményeket. ${ }^{13,15} \mathrm{~A}$ kitöltők válaszai alapján a magasabb idegen nyelvi kompetenciák minden szempontból növelték az interkulturális kompetencia szintjét, azonban a korábbi interkulturális kompetencia-képzés ugyan javította az ismereteket, de nem volt hatással a készségekre, a kultúrközi szituációkban való helytállásra vagy az attitűdökre. Számos specifikus, fejlesztendő területet azonosítottunk. A kapott válaszok alapján a „készségek”, valamint a "komfortérzet kultúrközi szituációkban” témakörök szempontjából a "kulturálisan szenzitív életvégi ellátás"; valamint a munkatársak, illetve kliensek „derogáló megjegyzéseivel szembeni megküzdés" bizonyult érzékeny és különösen fejlesztendő területnek. Igény mutatkozik olyan klinikai interkulturális kompetenciát fejlesztő kurzusok iránt, ahol nemcsak az elméleti, hanem a gyakorlati, szituatív oktatásra is nyitottak lennének a hallgatók. Annak ellenére, hogy nehézséget jelenthet egy-egy új kurzus alapképzésbe beillesztése a hallgatók túlterheltsége és időhiánya miatt, válaszadóink támogatják az interkulturális kompetencia fejlesztésére irányuló képzési modulok 
(pl. választható kurzusok, PhD és orvostovábbképző kurzus, stb.) indítását a bevándorlás aktualitása miatt, valamint a saját ismereteik, készségeik fejlódésének érdekében. Bízunk abban, hogy felmérésünk eredményeire és hallgatóink javaslataira alapozva a közeljövőben egy sikeres és eredményes új klinikai interkulturális kompetencia választható kurzust indíthatunk, és egy-két éven belül beszámolhatunk tapasztalatainkról is.

\section{TÁMOGATÁS}

„Az Emberi Erőforrások Minisztériuma ÚNKP-18-4 kódszámú, Új Nemzeti Kiválóság Programjának támogatásával készült". A kutatás a Magyar Tudományos Akadémia 'Bolyai János Kutatói Ösztöndíj' támogatásával valósult meg. Az ösztöndíjas időszak: 2017/09/01-2020/08/31. A kutatást támogatta a Pécsi Tudományegyetem, Általános Orvostudományi Kar, PTE ÁOK-KA [No. 2017-16].

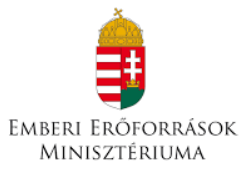

\section{HIVATKOZÁSOK}

\footnotetext{
${ }^{1}$ Stepping up action on refugee and migrant health. Outcome document of the High-level Meeting on Refugee and Migrant Health, 23-24 Nov, 2015, WHO, Rome, Italy http://www.euro.who.int/ data/assets/pdf file/0008/298196/ Stepping-up-action-on-refugee-migrant-health.pdf (Elérve: 2019. 06. 19.)

2 Betancourt JR, Green AR, Garrillo JE, et al. Defining cultural competence: a practical framework for addressing racial/ethnic disparities in health and health care. Public Health Reports. 2003;118(4):293-302. doi: $10.1093 / \mathrm{phr} / 118.4 .293$

${ }^{3}$ Rechel B, Mladovsky P, Ingleby D, et al. Migration and health in an increasingly diverse Europe. Lancet. 2013;381(9873):1235-1245. doi: 10.1016/S0140-6736(12)62086-8

${ }^{4}$ Like RC. Educating clinicians about cultural competence and disparities in health and health care. J Contin Educ Health Prof. 2011;31(3):196-206. doi: 10.1002/chp.20127

${ }^{5}$ Kagawa-Singer M, Kassim-Lakha S. A Strategy to Reduce Crosscultural Miscommunication and Increase the Likelihood of Improving Health Outcomes. Acad Med. 2003;78(6):577-587. doi: 10.1097/00001888-200306000-00006

${ }^{6}$ Beach MC, Price EG, Gary TL, et al. Cultural competency: A systematic review of health care provider educational interventions. Med Care. 2005;43(4):356-373. doi: 10.1097/01.mlr.0000156861.58905.96

${ }^{7}$ Betancourt JR, Green AR. Commentary: linking cultural competence training to improved health outcomes: perspectives from the field. Acad Med. 2010;85(4):583-585. doi: 10.1097/ACM.0b013e3181d2b2f3

8 Koehn PH, Swick HM. Medical Education for a Changing World: Moving Beyond Cultural Competence into Transnational Competence. Acad Med. 2006;81:548-556. doi: 10.1097/01.ACM.0000225217.15207.d4

${ }^{9}$ Kósa K, Lénárt B, Ádány R. A magyarországi cigány lakosság egészségi állapota. Orv Hetil. 2002;(143):419-2426.

${ }^{10}$ Neményi M. Cigány anyák az egészségügyben. http://mek.niif.hu/01100/01156/01156.htm (Elérve: 2019. 06. 19.)

${ }^{11}$ Faubl N, Császár Zs, Wusching ÁT, et al. Pécsett és Debrecenben tanuló külföldi orvostanhallgatók: egyetemválasztási és beilleszkedési kérdések. Metszetek. 2017;6(2):22-43. doi: 10.18392/metsz/2017/3/1

12 Like RC. Clinical cultural competency questionnaire (pre-training version). Center for Healthy Families and Cultural Diversity, Department of Family Medicine, UMDNJ-Robert Wood Johnson Medical School 2001.

http://rwjms.umdnj.edu/departments institutes/family medicine/chfcd/grants projects/documents/Pretraining.pdf (Elérve: 2019. 08. 05.)

${ }^{13}$ Ladson GM, Lin JM, Flores A, et al. An assessment of cultural competence of first-and second-year medical students at a historically diverse medical school. Am J Obst Gyn. 2006;195(5):1457-1462. doi: 10.1016/j.ajog.2006.06.051

${ }^{14}$ Christov-Moore L, Simpson EA, Coudé G, et al. Empathy: gender effects in brain and behavior. Neurosci Biobehav Rev. 2014;46:604-627. doi: 10.1016/j.neubiorev.2014.09.001

${ }^{15}$ Okoro ON, Odedina FT, Reams RR, et al. Clinical cultural competency and knowledge of health disparities among pharmacy students. Am J Pharm Educ. 2012;76(3):40. doi: 10.5688/ajpe76340
} 
${ }^{16}$ Grin F, Faniko K. Foreign language skills and intercultural abilities: Operationalization with a large population. Management \& Avenir. 2012;55(5):168-84. doi: 10.3917/mav.055.0168

17 Shapiro J, Lie D, Gutierrez D, et al. "That never would have occurred to me": a qualitative study of medical students" views of a cultural competence curriculum. BMC Med Educ. 2006;6(1):31. doi: 10.1186/1472-6920-6-31

${ }^{18}$ Krajic K, Stramayr C, Karl-Trummer U, et al. Improving ethnocultural competence of hospital staff by training: experiences from the European "Migrant-friendly Hospitals" project. Div Health Soc Care. 2005;2(4):279-290.

${ }^{19}$ Seeleman C, Hermans J, Lamkaddem M, et al. A students" survey of cultural competence as a basis for identifying gaps in the medical curriculum. BMC Med Educ. 2014;14(1):216. doi: 10.1186/1472-6920-14-216

${ }^{20}$ Knipper M, Seeleman IC, Essink ML. How should ethnic diversity be represented in medical curricula? A plea for systematic training in cultural competence. Tijdschrift voor Medisch Onderwijs. 2010;29(1):54-60.

doi: $10.3205 /$ zma000663

${ }^{21}$ Evans E. An elective course in cultural competence for healthcare professionals. Am J Pharm Educ. 2006;70(3):55. doi: 10.5688/aj700355

${ }^{22}$ Kahr-Gottlieb D, Papst P. Competence training for medical students in Austria. Eur J Public Health. 2013;23(suppl_1). doi: 10.1093/eurpub/ckt126.068 